\title{
Hybridization between Madagascan Red Fody Foudia madagascariensis and Seychelles Fody Foudia sechellarum on Aride Island, Seychelles
}

\author{
ROBERT S. LUCKING
}

\begin{abstract}
Summary
On islands where populations of the endemic Seychelles Fody Foudia sechellarum and the introduced Madagascan Red Fody F. madagascariensis coexist, previous studies have concluded that the two species are reproductively isolated. On Aride Island, Seychelles, one female $F$. sechellarum became established within a population of $F$. madagascariensis and produced at least two hybrid offspring. This paper describes the first known case of hybridization between the two species and highlights the possible biological consequences.
\end{abstract}

\section{Introduction}

The Ploceine genus Foudia is endemic to the western Indian Ocean and is represented by five extant species. Within the granitic islands of the Seychelles, two species of Foudia are present. The Madagascan Red Fody F. madagascariensis was introduced from Madagascar to the granitic Seychelles last century and is now one of the most abundant and widespread passerine bird species in the islands (Penny 1974). The endemic Seychelles Fody F. sechellarum is confined as a breeding species to the islands of Frégate, Cousin and Cousine in the granitic group of islands. In 1965, the Bristol Seychelles Expedition introduced five birds to D'Arros in the Amirantes (Gaymer et al. 1969) but this population was thought to have died out until an estimated 100 pairs were discovered on the island in May 1995 (A. Skerrett pers. comm. ). Historically, the Seychelles Fody was also found on Praslin, La Digue, Marianne and Aride (Collar and Stuart 1985). The species's extinction on these islands has been attributed to a combination of deforestation and the introduction of rats Rattus sp., mice Mus musculus and cats Felis domesticus (Crook 1961) although Diamond and Feare (1980) considered habitat change to have had a minor effect as Frégate Island holds four endemic bird species, is predator free and yet the vegetation is $95 \%$ exotic. On account of its limited distribution and evident susceptibility it is treated as"Vulnerable" by Collar et al. (1994).

Competition from the introduced $F$. madagascariensis has been thought responsible for the localized distribution of $F$. sechellarum (Vesey-Fitzgerald 1940, Moreau 1960), however no such evidence has been found (Crook 1961). On 
Frégate, feeding observations revealed that $F$. sechellarum was predominantly insectivorous, with insects forming $72 \%$ of the diet, seeds $25 \%$ and rotting fruit $3 \%$. F. madagascariensis was predominantly granivorous with $82 \%$ of feeding observations being on seed and $16 \%$ on insects (Crook 1961). On Cousin, Bathe and Bathe (1982) also found F. sechellarum to be predominantly insectivorous with $51 \%$ of the diet formed by insects, $38 \%$ by fruit and $11 \%$ by nectar.

Aride Island is the northernmost of the granitic Seychelles islands and is owned and managed as a nature reserve by the Royal Society for Nature Conservation (RSNC). Historically, Aride is thought to have had a resident breeding population of F. sechellarum (Diamond and Feare 1980) but it is uncertain when this population became extinct, although it must have been prior to 1940 when the species could only be found on Frégate, Cousin and Cousine (Vesey-Fitzgerald 1940). Aride does, however, have a resident breeding population of the introduced $F$. madagascariensis. It is not known when $F$. madagascariensis colonized Aride, although the species did not become established on Cousin until after 1940, or Cousine until 1958 despite both islands being less than $5 \mathrm{~km}$ from Praslin which was colonized in 1908 (Penny 1974). It is thus possible that populations of the two Foudia species have never coexisted on Aride. In August 1988, an immature F. sechellarum was discovered on Aride (Bullock 1989). It was assumed that strong southerly winds had blown the bird over from either Cousin or Cousine which lie approximately $20 \mathrm{~km}$ to the south of Aride. This bird was trapped and ringed in August 1993 and seen regularly until May 1994. In July 1994, another female F. sechellarum was found. This bird was caught and ringed in September 1994.

Hybridization has been recorded within the genus Foudia. In Madagascar, F. madagascariensis hybridizes with the Red Forest Fody F. eminentissima in areas where forest clearance has allowed $F$. madagascariensis to colonize areas previously only inhabited by the forest dwelling F. eminentissima (Dee 1986). In Mauritius, hybrids between $F$. rubra and F. madagascariensis have been reported and such a specimen is held at the British Museum (Moreau 1960). However Safford (1991) found no evidence of hybridization between the two species. In Seychelles, however, on the three islands where populations of both Foudia species coexist, comparative studies have concluded that both species coexist in complete reproductive isolation with no evidence of hybridization (e. g. Crook 1961). This paper describes the first example of hybridization between $F$. madagascariensis and $F$. sechellarum.

\section{Hybridization on Aride}

The presence of hybrid birds was first suspected in 1990 when one possible hybrid was noted (Castle and Mileto 1991). In December 1992, a young hybrid bird, presumably from a recent nesting attempt was seen begging from and being fed by a female $F$. sechellarum. Two subsequent nesting attempts by the female $F$. sechellarum were recorded. The first nest was constructed in January 1993 but was abandoned soon after completion with no signs of incubation noted. The second nest was built in July-August 1993 and the female was seen to be incubating. On 16 September 1993, the nest was examined and was found to contain two infertile eggs. The female was the only bird seen in close 
proximity to the nest and it is not known whether the bird was paired to a male F. madagascariensis.

In early 1993, a hybrid took up residence near the island's settlement and was seen regularly. It seemed to form a loose association with some of the resident $F$. madagascariensis although it was often seen chasing them, perhaps suggesting territorial behaviour. A second, different hybrid was later seen in the same area. On 9 September 1994, a hybrid was seen in the hill woodland. All previous sightings of hybrid birds, and indeed of F. sechellarum, had been on the coastal plateau. No signs of breeding behaviour by the hybrids were noted.

Visually, the hybrids resembled a drab female $F$. madagascariensis. The breast and flanks were dull brown, typical of $F$. sechellarum, but the back and mantle feathers had the prominent buff fringes giving the streaked back of $F$. madagascariensis. The hybrids had the facial markings of F. madagascariensis, including a prominent white supercilium which $F$. sechellarum lacks. Structurally, the hybrids were more akin to $F$. sechellarum. F. sechellarum is a dumpy-looking species with a comparatively short tail and a long stout bill. $F$. madagascariensis is much sleeker and longer-tailed with a shorter, almost conical bill. Figure 1 illustrates the structural and plumage differences between $F$. madagascariensis, F. sechellarum and the hybrid. Behaviourally the hybrids were similar to $F$. sechellarum. The hybrids displayed the characteristic wing-flicking behaviour of $F$. sechellarum and did not associate with the more gregarious $F$. madagascariensis or with other hybrids. The only vocalization heard was a sharp "tic-tic" not dissimilar to the European Robin Erithacus rubecula. F. sechellarum makes a similar call, a hollow sounding "tok-tok" whereas F. madagascariensis makes a variety of calls, the, most common being a high-pitched trilling.

On 15 August 1993, one of the hybrids was mist-netted, photographed, measured and ringed. Biometrics of the hybrid, F. madagascariensis and $F$. sechellarum are presented in Table 1 . The hybrid was heavier, had a shorter wing-length and a longer tarsus than both $F$. madagascariensis and F. sechellarum. The most striking difference was in bill shape. F. madagascariensis has a short, stubby bill whereas $F$. sechellarum has a longer, stouter bill to suit its largely insectivorous diet. The length of the hybrid's bill was intermediate between $F$. madagascariensis and $F$. sechellarum, but was narrower.

\section{Discussion}

The phenomenon of an introduced species interbreeding with an indigenous one can be cause for concern. In Spain, the White-headed Duck Oxyura leucocophela is in danger through interbreeding with the introduced Ruddy Duck $O$. jamaicensis, more so because the resultant hybrids are fertile (del Hoyo et al. 1992, Green and Anstey 1993). In the granitic islands of the Seychelles, the endemic subspecies of Malagasy Turtle Dove Streptopelia picturata rostrata is extinct through interbreeding with the introduced nominate form $S$. p. picturata (Penny 1974).

As hybridization between $F$. sechellarum and $F$. madagascariensis has never been noted on islands where breeding populations of both species coexist, it could be argued that the events on Aride are largely a result of a single female $F$. 


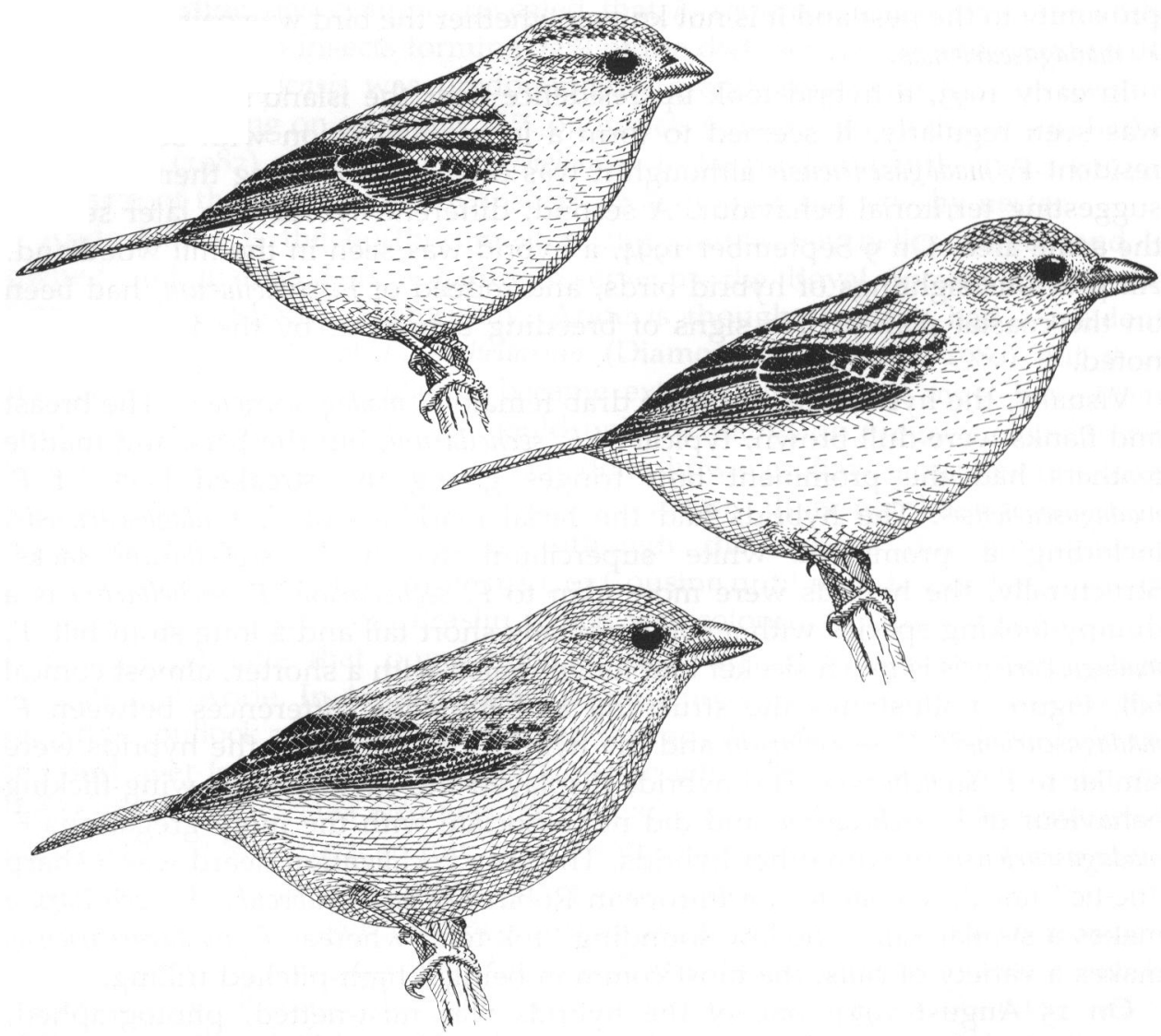

Figure 1. Scale illustrations of female $F$. madagascariensis (top), hybrid (middle) and $F$. sechellarum (bottom).

Table 1. Biometrics of F. madagascariensis, F. sechellarum and hybrid.

\begin{tabular}{lllc}
\hline & F. madagascariensis & F. sechellarum & Hybrid \\
\hline Weight $(\mathrm{g})$ & $15.2(13.5-16.5)$ & $16.9(15.9-19.1)$ & 19.9 \\
Wing length (mm) & $68.2(63.5-69.0)$ & $70.1(64.0-74.2)$ & 67.5 \\
Tail length (mm) & $45.4(41.1-48.4)$ & $45.5(42.3-48.0)$ & 46.0 \\
Tarsus length (mm) & $17.5(16.3-18.9)$ & $17.9(16.5-20.0)$ & 20.1 \\
Bill length (mm) & $13.0(9.2-13.8)$ & $16.3(12.3-18.3)$ & 15.1 \\
Bill depth (mm) & $10.4(9.7-11.1)$ & $10.9(9.2-14.0)$ & 7.9 \\
\hline
\end{tabular}

Numbers in parentheses indicate minimum and maximum ranges. $F$. madagascariensis and $F$. sechellarum biometrics from Crook (1961).

sechellarum within an established population of $F$. madagascariensis. As the dynamics of a natural recolonization process can be very slow indeed, it is likely that this situation on Aride will persist for many years.

In the two breeding attempts observed between November 1992 and November 1994, one resulted in no eggs being laid and the other in the laying of infertile eggs. However, hybridization can occur between the two species 
since two and possibly three hybrids were seen. Island forms are typically long-lived and it is possible that more hybrids may be produced in the future. The problem is compounded as it is unknown whether the hybrids themselves are fertile. If they are, this could endanger any future for F. sechellarum on Aride, and on neighbouring islands.

An essential first step should be to capture and destroy the hybrid birds. The removal of the female $F$. sechellarum would only be a short term solution as the arrival of further female birds cannot be ruled out. The most sensible long-term and lasting solution would be to translocate the basis of a viable, self-sustaining population of $F$. sechellarum to Aride, as recommended by Collar and Stuart (1985).

\section{Acknowledgements}

Many thanks to the two anonymous referees who made valuable comments on earlier drafts of the paper and to Nigel Bean for the excellent illustrations.

\section{References}

Bathe, H. and Bathe, G. (1982) Feeding studies of three endemic landbirds, Acrocephalus (= Bebrornis) sechellensis (Seychelles Brush Warbler), Foudia sechellarum (Seychelles Fody), and Nectarinia dussumieri (Seychelles Sunbird), on Cousin Island, Seychelles, with implications for their conservation through vegetation management. Unpublished.

Bullock, I. D. (1989) Aride Island Nature Reserve Scientific Report April 1987-April 1989, Part II. Birds, Mammals and Fish. Unpublished Report to RSNC, Lincoln.

Castle, G. E. and Mileto, R. (1991) Aride Island Scientific Report 1989-1991. Unpublished Report to RSNC, Lincoln.

Collar, N. J. and Stuart, S. N. (1985) Threatened birds of Africa and related islands. The ICBP/ IUCN Red Data Book, Part 1. Cambridge U.K.: International Council for Bird Preservation.

Collar, N. J., Crosby, M. J. and Stattersfield, A. J. (1994) Birds to watch 2. The world list of threatened birds. Cambridge, U.K.: BirdLife International.

Crook, J. H. (1961) The Fodies of the Seychelles islands. Ibis 103a: 517-548.

Dee, T. J. (1986) The endemic birds of Madagascar. Cambridge, U.K.: International Council for Bird Preservation.

del Hoyo, J., Elliot, A. and Sargatal, J. eds. (1992) Handbook of the birds of the world, 1. Barcelona: Lynx Edicions.

Diamond, A. W. and Feare, C. J. (1980) Past and present biogeography of central Seychelles birds. Pp. $89-98$ in Proceedings of the IV Pan-African Ornithological Congress.

Gaymer, R., Blackman, R. A. A., Dawson, P. G., Penny, M. and Penny, C. M. (1969) The endemic birds of Seychelles. Ibis 111: 157-176.

Green, A. J. and Anstey, S. (1993) The status of the White-headed Duck Oxyura leucocephala. Bird Conservation International 2: 185-200.

Moreau, R. E. (1960) The Ploceine Weavers of the Indian Ocean islands. J. Orn. 101: 29-49.

Penny, M. (1974) The birds of Seychelles and the outlying islands. London: Collins.

Safford, R. J. (1991) Status and ecology of the Mauritius Fody Foudia rubra and Mauritius Olive White-eye Zosterops chloronothos : two Mauritian passerines in danger. Dodo. J. Jersey Wildl. Preserv. Trust 27: 113-138. 
Vesey-Fitzgerald, D. (1940) The birds of the Seychelles. I. The endemic birds. Ibis 14: $480-489$.

\section{ROB LUCKING}

BirdLife International Seychelles Magpie-robin Recovery Programme, Frégate Island, PO Box 330, Victoria, Seychelles. 